\title{
Pengaruh Waktu Perendaman Air Garam Terhadap Penurunan Kadar Formalin Pada Cumi- Cumi Asin
}

\author{
Mimi Sugiarti, Siti Aminah \\ Jurusan Analis Kesehatan Politeknik Kesehatan Tanjungkarang
}

\begin{abstract}
Abstrak
Meski secara resmi formalin dilarang digunakan sebagai pengawet makanan namun kenyataan masih sering ditemukan makanan yang mengandung formalin. Tujuan penelitian untuk mengetahui berapa lama perendaman air garam yang paling baik untuk menghilangkan formalin. Penelitian dilakukan secara pra eksperimen dengan one-group pretest post test design. Penelitian ini dilakukan dengan merendam cumi-cumi asin yang mengandung formalin menggunakan air garam, dengan variasi waktu 15 menit, 30 menit, 60 menit dan 90 menit. Penelitian dilakukan di laboratorium Toksikologi Jurusan Analis Kesehatan Poltekkes Tanjungkarang. Pengukuran kadar formalin menggunakan spektrofotometer. Hasil penelitian menunjukkan ada penurunan kadar formalin setelah direndam dengan air garam selama 15 menit, 30 menit, 60 menit dan 90 menit, yaitu 37,3105\%, 49,3890\%, $54,7773 \%, 72,1172 \%$.
\end{abstract}

Kata Kunci : Formalin, cumi-cumi asin

\section{The Effect of Salt Water Damage Time To The Decrease of Formalin Levels in Sales}

\begin{abstract}
Abstrak
Although formalin is officially prohibited from being used as a food preservative, the reality is still often found food containing formalin. The purpose of this research is to find out how long and with what water best removes Formalin. Research is carried out experimentally by immersing squid containing formalin using salt water, time variation 15, 30, 60 and 90 minutes. The study was conducted in the Toxicology Laboratory of the Health Analyst Department of the Polytechnic of Tanjungkarang. Level measurement using a spectrophotometer. The results showed a decrease after being soaked with salt water for 15 minutes, 30 minutes, 60 minutes and 90 minutes: $37.3105 \%, 49.3890 \%, 54.7773 \%, 72.1172 \%$.
\end{abstract}

Keywords: Formalin, salted squid

Korespondensi: Mimi Sugiarti, Jurusan Analis Kesehatan Politeknik Kesehatan Tanjungkarang, Jalan Soekarno-Hatta No. 1 Bandar Lampung, mobile 081214886917, e-mail mimisugiarti@poltekkes-tjk.ac.id 


\section{Pendahuluan}

Peningkatan mutu kesehatan pangan telah diupayakan oleh pemerintah sejak tahun 1996, melalui undang undang nomor 7 Tahun 1996 yang menyatakan bahwa kualitas pangan yang dikonsumsi harus memenuhi beberapa kriteria diantaranya adalah aman, bergizi, bermutu, dan dapat terjangkau oleh daya beli masyarakat. Dengan adanya umdang-undang tersebut diharapkan Indonesia dapat terhindar dari cemaran makanan yang dapat membahayakan kesehatan manusia ( UU M0.7/ 96).

Kenyataannya masih ada produsen yang masih menggunakan bahan tanbahan makanan yang dilarang digunakan untuk makanan salah satunya adalah formalin. Formalin, merupakan salah satu bahan tambahan makanan yang dilarang terdapat dalam makanan. Formalin adalah aldehida dengan rumus kimia $\mathrm{H}_{2} \mathrm{CO}$ yang berbentuk gas atau cair yang dikenal sebagai formalin. Formaldehida biasa larut dalam air dan mengalami polimerisasi sehingga sedikit sekali yang ada dalam bentuk monomer $\mathrm{H}_{2} \mathrm{CO}$. Formalin adalah larutan formaldehida dalam air, dengan kadar antara 10\%-40\% (Anonim, 2015).

Formalin merupakan bahan yang digunakan untuk mengawetkan mayat atau preparat biologi. Fungsi formalin sebagai pengawet ini disebabkan karena ikatan yang terbentuk antara formalin dan protein dapat membunuh bakteri dengan membuat jaringan dalam bakteri dehidrasi, sehingga sel bakteri akan kering dan membentuk lapisan baru di permukaan. Artinya, formalin tidak hanya membunuh bakteri, tetapi juga membentuk lapisan baru yang melindungi lapisan di bawahnya agar tahan terhadap serangan bakteri lain.

Sebagai pengawet formalin dilarang digunakan dalam pengawetan makanan atau minuman karena residu formalin mengganggu kesehatan bagi yang memakannya. Menurut Internasional Programne on Chemical Safety (IPCS) batas aman formaldehid secara ingesti adalah 2,6 mg/liter berdasarkan non observed effect level (NOEL) $260 \mathrm{mg} /$ liter pada mukosa lambung tikus yang diberi minum selama 2 tahun. Dampak formalin pada kesehatan manusia menyebabkan iritasi pada mata dan saluran pernapasan, alergi pada kulit dan paruparu (Anonim, 2005).

Secara resmi formalin dilarang digunakan sebagai pengawet makanan namun kenyataan masih sering ditemukan makanan yang mengandung formalin. Salah satu nya adalah ditemukannya formalin pada cumi asin yang dijual di pasar, seperti hasil penelitian yang dilakukan oleh Deny Agung Putra 2014 ditemukan Formalin pada ikan asin yang dijual di pasar Bandarjaya Lampung Tengah. BPOM Bandar Lampung menemukan hasil positif Formalin pada cumi asin sebesar 170 ppm di Pulau pasaran Kota Karang Bandar Lampung.

Meski demikian ada cara menghilangkan formalin pada makanan sebelum dimasak. Sehingga kandungan formalin akan berkurang bahkan hilang. Cara yang bisa dilakukan cukup sederhana dan mudah dilakukan.

Pengurangan Residu Formalin dalam makanan ini penting dilakukan mengingat bahaya yang bisa ditimbulkan oleh formalin tersebut. Ada beberapa cara yang bisa dilakukan untuk mengurangi residu formalin pada makanan .

Karakteristik risiko yang membahayakan bagi kesehatan manusia yang berhubungan dengan formalin adalah berdasarkan konsentrasi dari substansi formalin yang terdapat di udara dan juga dalam produk-produk pangan (Cahyadi 2009). Formalin bila menguap di udara, berupa gas tidak berwarna, dengan bau yang tajam menyesakkan sehingga merangsang hidung, tenggorokan dan mata (cahyadi,2009).

Formalin dapat masuk ke dalam tubuh dengan jalan inhalasi uap, kontak langsung dengan larutan yang mengandung formalin atau dengan jalan memakan atau meminum makanan yang mengandung formalin (Cahyadi, 2009).

Berdasarkan Intergrate Risk Information System (IRIS) penggunaan formalin sebesar 0,2 $\mathrm{mg} / \mathrm{kg} / \mathrm{hari}$ sudah dapat menimbulkan gangguan umum pada konsumen. Nilai tersebut merupakan dosis refrensi (RfD) yaitu nilai ambang batas terkecil pengguna formalin yang diterima oleh tubuh untuk mendapatkan efek racun (Epa, 2007).

Apabila sering mengkonsumsi makanan atau minuman yang mengandung formalin dalam dosis yang tinggi dapat mengakibatkan konvulsi (kejang-kejang), haematuria (kencing darah) dan muntah darah yang berakhir dengan kematian. Injeksi formalin dengan dosis $100 \mathrm{gr}$ dapat mengakibatkan kematian dalam waktu 3 jam (winarno,2004).

Mengenai sifatnya yang karsinogenik, formalin termasuk ke dalam karsinogenik golongan IIA.Golongan I adalah yang sudah pasti menyebabkan kanker, berdasarkan uji lengkap. Sedangkan golongan IIA baru taraf diduga, karena data hasil uji pada manusia masih kurang lengkap. (cahyadi,2009) 


\section{Metode}

Jenis penelitian adalah pra eksperimen dengan one-group pretest post test design. Pemeriksaan kadar formalin dilakukan secara kualitatif dan kuantitatif. Peemriksaan secara kualitatif, yaitu menggunakan reaksi asam kromatopat. Jika reaksi berubah menjadi warna ungu, maka menunjukan hasil positif adanya formalin. Jika positif, maka dilanjutkan secara kuantitatif menggunakan spektrofotometer untuk mengukur kadar formalin. Pengukuran kadar sebelum diberi perlakuan dan setelah perlakuan dengan merendam cumi asin berformalin menggunakan air garam kemudian dilakukan pemeriksaan kadar formalinnya setelah 15 menit, 30 menit, 60 menit dan 90 menit.Variabel pada penelitian ini adalah waktu perendaman dan kadar formalin pada cumi asin.

Penelitian dilakukan di Laboratorium Toksikologi Jurusan Analis kesehatan Poltekkes Tanjungkarang, waktu penelitian dilakukan pada bulan Juni sampai dengan
September 2018. Subjek pada penelitian ini adalah cumi-cumi asin berformalin yang dijual di Pasar Bandar Lampung.

\section{Hasil}

Kualitatif

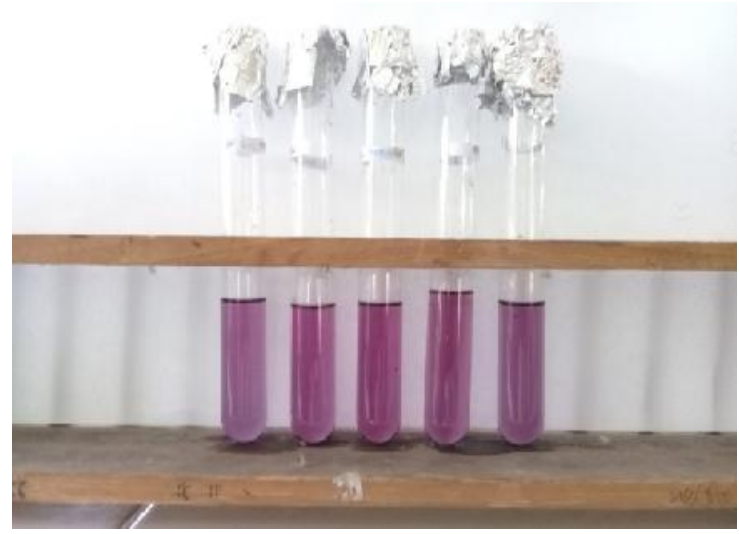

Gambar 1. Hasil pemeriksaan kualitatif dengan reaksi asam Kromatopat, warna ungu menunjukan hasil positif

Tabel 1. Hasil pemeriksaan sampel cumi-cumi asin secara kualitatif dengan menggunakan asam kromatopat.

\begin{tabular}{ccccccccccc}
\hline No & $\mathbf{1}$ & $\mathbf{2}$ & $\mathbf{3}$ & $\mathbf{4}$ & $\mathbf{5}$ & $\mathbf{6}$ & $\mathbf{7}$ & $\mathbf{8}$ & $\mathbf{9}$ & $\mathbf{1 0}$ \\
\hline Warna & Ungu & Ungu & Ungu & Ungu & Ungu & Ungu & Ungu & Ungu & Ungu & Ungu \\
Hasil & + & + & + & + & + & + & + & + & + & +
\end{tabular}

Sampel diperiksa secara kualitatif menggunakan asam kromatofat dan hasilnya seluruh sampel berwarna ungu ,menandakan Formalin Positif (+).

Dilanjutkan dengan uji kuantitatif menggunakan Fotometer didapatkan hasil sebagai berikut :

\section{Kuantitatif \\ 1. Univariat}

Tabel 2. Distribusi Frekuensi kadar Formalin pada cumi asin sebelum direndam

\begin{tabular}{ccc}
\hline $\begin{array}{c}\text { Kadar tertinggi } \\
\text { (dalam ppm) }\end{array}$ & $\begin{array}{c}\text { Kadar terendah } \\
\text { (dalam ppm) }\end{array}$ & $\begin{array}{c}\text { Rata rata } \\
\text { (dalam ppm) }\end{array}$ \\
\hline 1.7567 & 1.2157 & 1.4977 \\
\hline
\end{tabular}

Tabel 3. Distribusi Frekuensi kadar Formalin

\begin{tabular}{ccccc}
\multicolumn{6}{c}{ setelah direndam dengan air } & garam . \\
\hline No & $\begin{array}{c}\text { Waktu } \\
\text { perenda } \\
\text { man }\end{array}$ & $\begin{array}{c}\text { Kadar } \\
\text { Terting } \\
\text { gi (pp) }\end{array}$ & $\begin{array}{c}\text { Kadar } \\
\text { terenda } \\
\text { h(ppm) }\end{array}$ & $\begin{array}{c}\text { Rata }- \\
\text { rata } \\
\text { (ppm) }\end{array}$ \\
\hline 1 & 15 Menit & 1.0520 & 0.8580 & 0.9389 \\
2 & 30 Menit & 0.7955 & 0.7330 & 0.7580 \\
3 & 60 menit & 0.7273 & 0.6818 & 0.6773 \\
4 & 90 menit & 0.6364 & 0.2727 & 0.4176 \\
\hline
\end{tabular}

Tabel 4. Persentasi penurunan kadar Formalin setelah direndam dengan air garam

\begin{tabular}{clc}
\hline No & Waktu Perendaman & \% Penurunn \\
\hline 1 & 15 Menit & $37,3105 \%$ \\
2 & 30 menit & $49,3890 \%$ \\
3 & 60 Menit & $54,7773 \%$ \\
4 & 90 Menit & $72,1172 \%$ \\
\hline
\end{tabular}

2. Bivariat

Regresi linier dengan variabel dependent besar penurunan formalin (nilai relatif/ prosentase)

Ada perbedaan besar penurunan kadar formalin pada keempat waktu $\left(\mathrm{P}_{\text {Value }}=0,000\right)$

Ada perbedaan prosentase penurunan kadar formalin pada keempat waktu $\left(\mathrm{P}_{\text {Value }}=\right.$ 0,000)

Waktu terbaik $=90$ menit. 60 menit beda dengan 90 menit, tetapi sama dengan 30 menit

\section{Pembahasan}

Dari hasil penelitian didapatkan seluruh sampel cumi-cumi positif mengandung 
Formalin, hal ini terlihat dari pemeriksaan secara kualitatif menggunakan Asam kromatopat yang menghasilkan larutan berwarna ungu.

Penelitian dilanjutkan dengan pemeriksaan secara kuantitatif menggunakan fotometer. Sampel diberi perlakuan berupa perendaman dengan air garam konsentrasi $5 \%$. Perendaman dilakukan dengan 4( empat) durasi waktu yaitu 15 menit, 30 menit, 60 menit dan 90 menit. Setiap varian waktu diulang sebanyak 10 kali sehingga total percobaan adalah 40 kali.

Berdasarkan hasil pemeriksaan sampel cumi-cumi asin di Laboratorium secara fotometer didapatkan kadar Formalin tertinggi sebesar $1,7567 \mathrm{ppm}$, terendah $1,2157 \mathrm{ppm}$ dan arata-rata mengandung 1,4977 ppm Formalin. Hal ini menunjukkan bahwa masih banyak produsen ikan cumi-cumi asin yang menggunakan formalin sebagai pengwet pada ikan yang mereka olah.

Hal ini sejalan dengan penelitian yang dilakukan oleh Deny Agung Putra (2014) ditemukan Formalin pada ikan asin yang dijual di pasar Bandar Jaya Lampung Tengah. BPOM Bandar Lampung (2005) menemukan hasil positif formalin pada cumi asin di Pulau pasaran Kota Karang Bandar Lampung.

Peneliti kemudian melakukan perlakuan terhadap cumi-cumi asin dengan melakukan perendaman menggunakan air garam selama 15 menit terjadi penurunan sebesar 37,3105\%30 menit sebesar 49,3890\%, 60 menit sebesar $54,7773 \%$ dan 90 menit sebesar 72,1172\%.

Dilihat dari persentasi penurunan maka penurunan tertinggi terjadi pada perendaman dengan waktu 90 menit.

Dilihat dari variasi waktu yang digunakan untuk merendam terdapat perbedaan penurunan dan perbedaan besarnya presentase penurunan kadar formalin pada ke empat variasi waktu tersebut. Waktu perendaman terbaik untuk menurunkan kadar formalin pada cumicumi asin adalah 90 menit.

Air garam mampu menurunkan kadar formalin sebesar $72,1172 \%$ dengan waktu perendaman 90 menit, hal ini sejalan dengan penelitian yang dilakukan oleh Ayu Ermawati . Terjadi penurunan kadar formalin pada ikan teri sebesar 3,6\% setelah direndam dengan air garam dan terjadi penurunan sebesar 3,25\% setelah direndam dengan air hangat.

Formalin yang dicampurkan dalam makanan yang mengandung protein akan menyebabkan reaksi spontan antara gugus aldehid formalin dengan protein sehingga terbentuk ikatan metilen $(\mathrm{NCHOH})$ yang bersifat reversible.

Kandungan formalin dalam cumi-cumi dapat dikurangi dengan direndam dalam air karena formalin bersifat larut dalam air, sehingga dengan perendaman formalin yang ada pada cumi-cumi akan larut dalam pelarutnya yaitu air. Hal tersebut terjadi karena terdapat perbedaan tekanan osmosis antara daging cumi-cumi dengan larutan perendamnya yaitu air,sehingga terjadilah perpindahan molekul dari daging cumi ke air perendamnya.Formalin berbentuk polar melalui proses perendaman molekul ini maka formalin mempunyai sifat larut dalam air karena formalin bersifat polar dan air juga bersifat polar (Farid, 2015).

Kelarutan garam dalam air menyebabkan kelarutan oksigen dalam air menurun. Perendaman dalam larutan garam akan menurunkan residu formalin pada cumi-cumi asin karena perbedaan tekanan osmosis antara cairan sel padatan cumi-cumi asin dengan larutan garam perendam akan menyebabkan berlangsungnya proses difusi cairan dari padatan cumi-cumi asin ke dalam larutan garam. Difusi cairan sel membawa molekul formalin yang terlarut dalam cairan sel padatan cumi-cumi asin. Proses difusi ini akan dipengaruhi oleh perbedaan tekanan osmosis, waktu perendaman dan suhu larutan garam. Semakin besar perbedaan osmosis, semakin lama waktu perendam, akan semakin banyak formalin yang berdifusi ke larutan air garam sampai tercapai kondisi larutan jenuh. Demikianjuga semakin tinggi suhu larutan perendam akan semakin cepat proses difusi formalin ke dalam larutan perendam, sehingga semakin banyak formalin yang tercuci (Yuniarti, 2013).

Simpulan hasil penelitian ini terjadi penurunan kadar Formalin setelah direndam dengan air garam selama 15 menit, 30 menit, 60 menit dan 90 menit adalah sebagai berikut: $37,3105 \%, 49,3890 \%, 54,7773 \%, 72,1172 \%$

\section{Daftar Pustaka}

Anonim³. Tekno Pangan \& Agroindustri. Bogor: IPB

Anonim ${ }^{4}$. Undang-Undang Republik Indonesia Nomor 7 Tahun 1996

Badan POM RI.2006.Metode Analisis Pemeriksaan Kadar Formaldehid dalam Makanan.

Cahyadi, Wisnu.2009.Analisis dan Aspek Kesehatan Bahan Tambahan 
Pangan.Edisi Kedua. Jakarta: PT Bumi Aksara.

Formaldehyde,

Tersedia

http://www.chemnet.com/cas/my/50-00-

0/Formaldehyde.html. Diakses tanggal 5 agustus 2014

DirjenPOM.1990. Pedoman Pemeriksaan Makanan.Jilid 1. Jakarta: Depkes RI.

Epa ,2007. Formaldehdye. Tersedia http://www.epa.gov/iris/subst/0419.html. Diakses tanggal 5 agustus 2014

Farmakope Indonesia edisi IV.1995. Depkes RI.

Fessenden,R.J dan Fessenden,J.S.1982. Kimia Organik. Edisi Ketiga. Jilid 2. Jakarta: Erlangga.

Jurnalnet.2005. Formalin di makanan tak bisa dihilangkan.Tersedia http://www.jurnalnet.com/konten.php?na ma=BeritaUtama\&topik=7\&id=501. Diakses tanggal 2 Januari 2014 .

Mona Dela Rose Sirait. 2016 . Pengaruh Perendaman dalam larutan garam Terhadap Penurunan residu Formalin pada Tahu ,Skripsi Universitas Lampung

Winarno, F.G., 2004. Keamanan Pangan jilid.Bogor: M-Brio Press. 